HESWBL

9,1

Received 7 February 2018 Revised 30 April 2018 Accepted 20 June 2018

\section{Identity, employability and entrepreneurship: the ChANGE framework of graduate attributes}

\author{
Rachel Maxwell and Alejandro Armellini \\ Institute of Learning and Teaching in Higher Education, \\ The University of Northampton, Northampton, UK
}

\begin{abstract}
Purpose - The purpose of this paper is to introduce an evidence-based, transferable framework of graduate attributes and associated university toolkit to support the writing of level-appropriate learning outcomes that enable the university to achieve its mission to Transform Lives + Inspire Change.

Design/methodology/approach - An iterative process of co-design and co-development was employed to produce both the framework and the associated learning outcomes toolkit.

Findings - There is tangible benefit in adopting an integrated framework that enables students to develop personal literacy and graduate identity. The toolkit enables staff to write assessable learning outcomes that support student progression and enable achievement of the framework objective.

Research limitations/implications - While the framework has been in use for two years, institutional use of the toolkit is still in its early stages. Phase 2 of the project will explore how effectively the toolkit achieves the framework objective.

Practical implications - The introduction of a consistent, integrated framework enables students to develop and actively increase personal literacy through the deliberate construction of their unique graduate identity. Social implications - Embedding the institutional Changemaker attributes alongside the agreed employability skills enables students to develop and articulate specifically what it means to be a "Northampton graduate".

Originality/value - The uniqueness of this project is the student-centred framework and the combination of curricular, extra- and co-curricular initiatives that provide a consistent language around employability across disciplines. This is achieved through use of the learning outcomes toolkit to scaffold student progression.

Keywords Active blended learning, ChANGE, COGS, Employability and entrepreneurship,

Graduate identity, Personal literacy
\end{abstract}

Paper type Research paper

\section{Introduction}

Twenty-first century UK Higher Education operates in a complex setting, characterised by multiple and intertwined demands and constraints. Among them, the focus on widening access, student choice, teaching excellence and a range of metrics surrounding graduate employability. Also of relevance here is the increasing marketization of higher education (Blackmore et al., 2016; Pemberton et al., 2013; Wilton, 2014) prompting many Higher Education Providers (HEPs) to reposition themselves as "market-orientated educational enterprises" (Grotkowska et al., 2015) through focussing on the personal development of students and, ultimately, their preparedness for future employment.

At a strategic level, the University of Northampton's response to these demands and constraints is encapsulated in the 2015-2020 strategic plan - Transforming Lives + Inspiring Change - in a way that "strip[s] out complexity and [forces us to] think [...] radically about how to create a University that competes with the world on its own terms, not those dictated by others" (The University of Northampton, 2015). Operationally - and

\footnotetext{
(C) Rachel Maxwell and Alejandro Armellini. Published by Emerald Publishing Limited. This article is published under the Creative Commons Attribution (CC BY 4.0) licence. Anyone may reproduce, distribute, translate and create derivative works of this article (for both commercial and non-commercial purposes), subject to full attribution to the original publication and authors. The full terms of this licence may be seen at http://creativecommons.org/licences/by/4.0/legalcode
} 
for the purposes of this paper - there are two main responses. First, a requirement to "create a unique learning and teaching model" (The University of Northampton, 2015). Second, the creation of an institutional culture that encourages all staff and students to be "Changemakers" - defined at its simplest as "seeing a social problem and doing something about it". From a student perspective, the former of these offers an innovative context in which the latter can become part of all programmes and modules. Students can therefore explore their own capacity as Changemakers through engagement with a new framework that symbiotically unites curricular, extra- and co-curricular initiatives to support graduate employability.

In this paper we report on four main aspects emerging from the University's approach to becoming an entrepreneurial institution and the resulting benefits to students:

(1) the impact of combining two previously separate strands of work to support graduate employability into a single, unified, student-centred framework of graduate attributes that supports not only "graduate-ness" in general but, more specifically, an individual's identity as a University of Northampton graduate;

(2) the value from embedding the new framework across all curricula as part of a broader context of large-scale pedagogic change;

(3) the development of Changemaker attributes in students at all academic levels through the introduction of the Changemaker Outcomes for Graduate Success toolkit, which helps staff to develop learning outcomes by level and supports student progression; and

(4) a scheme that enables the development of on-programme employability and Changemaker skills through a focus on personal literacy for successful graduate employment.

The paper concludes with a reflection on the progress made in relation to these four aspects, identifies some of the risks and limitations with this work and points to some of the challenges ahead. It recognises that the development of the ChANGE framework per se is no guarantee that students will develop the ChANGE attributes. As such, phase 2 of the ChANGE project (now underway) is supporting staff to embed the attributes within all subject areas through the writing of assessable module learning outcomes that evidence a constructively aligned approach to curriculum design (Biggs and Tang, 2011). The paper also puts forward a set of ideas that other higher education institutions may wish to consider as they attempt to transform the opportunities for all students.

\section{Phase 1: two separate strands of work}

This section details the evolution of two separate initiatives, each designed to support and develop students' graduate employability potential at Northampton (Figure 1), but addressing different aspects of the student experience. The first strand looks at the work of the University Centre for Employability and Engagement (UCEE) (now renamed the Changemaker Hub) in supporting graduate employability, careers development, volunteering and placement activity in the extra- and co-curricular sphere through their
The ChANGE framework of graduate attributes 
HESWBL 9,1
"Employability Plus" initiative. The second strand focusses on the work conducted by Northampton's Institute of Learning and Teaching in Higher Education (ILT) to articulate and deliver the strategic mission to transform lives and inspire change in all academic programmes.

This work resulted in a series of initiatives under the banner of the "Changemaker in the Curriculum" project, with its focus on the enhancement of graduate prospects through socially entrepreneurial, enterprise behaviour. The Organisation for Economic Co-operation and Development has consistently highlighted this focus as necessary for Universities (and economies) to actively engage with to support ongoing economic and social development (Marringe and Foskett, 2010, cited in Cavanagh et al., 2015).

Strand 1: extra- and co-curricular support for employability at the University of Northampton The widely accepted definition of employability developed by Yorke and Knight (2006) offered a meaningful starting point to support graduate employability at the University of Northampton and ultimately enabled the articulation of what it means to be a "Northampton graduate". In their definition, employability is:

A set of achievements - skills, understandings and personal attributes - that make individuals more likely to gain employment and be successful in their chosen occupations, which benefits themselves, the workforce, the community and the economy (Yorke and Knight, 2006, p. 3).

Employability is therefore clearly more than a set of skills (Holmes, 2001). The term "skills" throughout this paper should therefore be assumed to encompass attributes, capabilities and behaviours, all of which combine and need to be evidenced by the individual upon entry to, and future transfer within, the labour market (Yorke, 2006). Given the complexity of developing an inter-connected institutional response to the graduate employability imperative, it is not surprising that there is no single authoritative set of skills that employers want from graduates (Artess et al., 2016; Higher Education Academy, 2015). Rather employability offerings have been contextualised by country (Oria, 2012), by workforce sector (Hinchliffe and Jolly, 2011; Rich, 2015; Shah et al., 2004) or, as in the case of Northampton, by the University's strategic mission.

To meet the needs of all 13,000+ students at Northampton, the UCEE made a strategic decision to move away from the more traditional "careers service" approach of 1:1 appointments that had, until this time, prevailed at Northampton. The new scheme, "Employability Plus", makes increased use of a "flipped" approach to careers development, an approach which, as Greenbank (2015) argues, is more likely to engender behavioural change.

At Northampton, this introduction of more "transformative pedagogies" (Artess et al., 2016, p. 7) by the "careers service" was strengthened with the allocation of responsibility for engaging staff and students in our values-driven "Changemaker agenda" to the UCEE team. Situating these dual responsibilities in the same department explicitly recognised the symbiosis between the employability agenda and "changemaking" or entrepreneurial behaviours. It subsequently helped to articulate the notion of the "Northampton graduate" through the development of a unified, values-driven employability framework. This resonates strongly with what Artess et al. (2016) describe as a subtle discussion of "identity" (p. 7) as the individual transitions from student to graduate employee and citizen. This expansion of the discourse takes preparedness for employability well beyond skills acquisition, and into exploration of personal characteristics, attributes and behaviours that identify "graduate-ness" (Hinchliffe and Jolly, 2011; Kalfa and Taksa, 2015; Daniels and Brooker, 2014; Cutts et al., 2015), all of which are directly relevant to the University's Changemaker agenda. The revised QAA Guidance on Enterprise and Entrepreneurship Education signals the extent to which these "enterprise competencies" are now viewed as 
"essential attributes [...] identified by employers as priorities" (Quality Assurance Agency for Higher Education (QAA), 2018, p. 3).

A final consequence of combining responsibilities for graduate employability and Changemaking in the same department has been to preserve the critical role played by these services in curriculum development as well as in co- and extra-curricular work and employer engagement provision, thereby reducing the risk of the service becoming increasingly marginalised (Andrews and Russell, 2012).

\section{Strand 2: "Changemaker in the Curriculum"}

At a strategic level, the University of Northampton has sought to develop a "sustainable approach to improving society by taking positive action to address social problems" (Alden Rivers, Armellini, Maxwell, Allen and Durkin, 2015, p. 385). For many of our students, this sustainability has been realised through opportunities to engage academically and practically with social innovation through their academic studies. However, it was necessary to mainstream these opportunities and make them available to all students to genuinely fulfil the strategic intent to transform lives and inspire change. In so doing, this work helps meet a key policy initiative identified by the European Commission's Joint Research Centre, namely "improving "university-business engagement and developing enhanced links between employment and innovation" (QAA, 2018, p. 6).

Through a phenomenographic study to kick-start our "Changemaker in the Curriculum" project, a research team based in ILT identified five "Conceptions of Changemaker": Changemaker as University strategy; Changemaker as critical thinking, perspective shifting and problem solving; Changemaker as enhancing employability; Changemaker as social betterment; and Changemaker as personal transformation (Alden Rivers, Nie and Armellini, 2015).

Having identified these conceptions, the project team turned its attention to deconstructing them so that they could be embedded into discipline curricula. This work identified a set of Changemaker attributes that encapsulated the skills and behaviours understood by the study participants as being inherently "Changemaker" in nature. Furthermore, it then became possible to consider explicitly how Changemaker could inform the design, development, delivery and review of all academic programmes and how those Changemaker attributes might inform the writing of Programme and Module Learning Outcomes across academic levels and disciplines in a manner suitable for assessment. Ultimately, as students engaged with the Changemaker attributes as part of their studies, they would acquire an individualised "Changemaker difference" upon graduation influenced by their academic programme of study, their own identity (both as an individual and as a graduate of the University of Northampton) and the needs required for working in either entrepreneurial or intrapreneurial contexts (see further QAA, 2018).

\section{Enabling two to become one: the impact of institutional pedagogic change through the} introduction of "active blended learning ( $A B L)$ "

At the heart of the University of Northampton strategic plan 2015-2020 is an imperative to "create a unique Learning and Teaching model" that will provide a clearly identifiable element of differentiation from competitors (The University of Northampton, 2015, p. 4). Led by ILT, this project sought to conceptualise and ultimately formalise this model, consistent with the Changemaker in the Curriculum initiative.

In 2013, the university embarked on a large-scale project of programme design and redesign for ABL, the new pedagogic model. The project served as a catalyst that eventually drew the two strands of work around employability and Changemaker together. 
HESWBL 9,1

It became clear early on that if staff were redesigning their learning and teaching in line with $\mathrm{ABL}$, then there was merit in simultaneously embedding the employability skills and Changemaker attributes.

$\mathrm{ABL}$ is a wholesale, deliberate move away from a standard "lecture-seminar" mode of delivery. The agreed definition of ABL surfaces the strategic importance of developing employability skills, capabilities and behaviours within the curriculum, demonstrating how embedded and linked these different concepts have become:

[An ABL] programme is taught through student-centred activities that support the development of subject knowledge and understanding, independent learning and digital fluency. Our face-to-face teaching is facilitated in a practical and collaborative manner, clearly linked to learning activity outside the classroom. Opportunities are provided for students to develop autonomy, Changemaker attributes and employability skills (Institute of Learning and Teaching in Higher Education, 2016a, emphases added).

The inclusion of Changemaker in this definition will ensure all students receive an entitlement to engage with the Changemaker principles and practice, with a view to enhancing their overall employability potential and developing their own identity as "Northampton graduates".

\section{Phase 2: development of the ChANGE framework (Changemaking at Northampton for Graduate Employability)}

Initial work to draw the Employability and Changemaker projects together accorded primacy to the Changemaker attributes (Alden Rivers, Armellini, Maxwell, Allen and Durkin, 2015). However, it quickly became clear that the real value to students lay in reinforcing the Employability Plus framework as these skills were already familiar to current students and, importantly, to employers (Table I). That said, the most recent QAA (2018) Guidance on Enterprise and Entrepreneurship Education suggests that the language of entrepreneurship education is becoming more widely understood and accepted within the HE Sector and by employers.

Although the Employability Plus and Changemaker in the Curriculum initiatives were both always intended to support individual student skills development, reversing the mapping in this way offered considerably increased scope for a genuinely student-centred model that has the potential to significantly increase individual propensity to secure graduate level employment than existed when the two strands remained independent (Figure 2).

While students will need to adopt the language of employability skills rather than "changemaking" in order to achieve success within the labour market, recent evidence suggests that "enterpreneurial competencies" as a phrase is becoming more widely understood and accepted and their overlap with more traditional "employability skills" recognised (QAA, 2018). Ultimately, students not only need to know what employers are looking for in university graduates, they also need to turn this awareness into action and articulate the possession of those skills when entering or moving within the labour market.

The need for "personal literacy" (informed by the development of their "Changemaker literacy" at Northampton) - the ability of an individual to demonstrate self-awareness in their learning and operational spheres and function collaboratively with others autonomously, effectively and independently (Oxford Brookes University, 2010) - is met via the ABL methodology through its deliberate focus on what students do with what they know, or how they apply their knowledge in practice, depending on the nature of the discipline being studied. Personal literacy is scaffolded through the multiple structured and yet personalised opportunities offered through "Employability Plus" for students to be aware of their own "propensity [...] to know what skills they have developed and match 


\begin{tabular}{|c|c|c|c|}
\hline \multirow{2}{*}{$\frac{\text { "Employability Plus" skill }}{\text { Communication }}$} & \multicolumn{2}{|c|}{ Changemaker attributes } & The ChANGE \\
\hline & Self-confidence & Communication & graduate \\
\hline & Empathy & Emotional and social intelligence & \\
\hline \multirow[t]{3}{*}{ (Group and) team work } & Self-confidence & Communication & attributes \\
\hline & Self-awareness & Emotional and social intelligence & \\
\hline & $\begin{array}{l}\text { Empathy } \\
\text { Problem-solving }\end{array}$ & Innovation and creativity & 81 \\
\hline \multirow[t]{2}{*}{ Positive work ethic } & Self-confidence & Internal locus of control & \\
\hline & $\begin{array}{l}\text { Perseverance } \\
\text { Action orientation }\end{array}$ & Critical thinking & \\
\hline \multirow[t]{2}{*}{ Networking } & Self-confidence & Empathy & \\
\hline & Self-awareness & Communication & \\
\hline Organisation and action planning & Internal locus of control & $\begin{array}{l}\text { Perseverance } \\
\text { Action orientation }\end{array}$ & \\
\hline \multirow[t]{4}{*}{ Problem solving, analysis and investigation } & Perseverance & Innovation and creativity & \\
\hline & Internal locus of control & Critical thinking & \\
\hline & Action orientation & Reflective & \\
\hline & & Problem-solving & \\
\hline \multirow[t]{3}{*}{ Self-management (and reflective learning) } & Internal locus of control & Critical thinking & \\
\hline & Self-awareness & Reflective & \\
\hline & Action orientation & Values-driven & \\
\hline \multirow[t]{4}{*}{ Leadership } & Self-confidence & Emotional and social intelligence & \\
\hline & Self-awareness & Leader & \\
\hline & Action orientation & Values-driven & \\
\hline & Communication & & \\
\hline \multirow[t]{2}{*}{ Opportunity recognition } & Action orientation & Perseverance & Table I. \\
\hline & Innovation and creativity & Reflective & Mapping of \\
\hline \multirow[t]{3}{*}{ Persuading, influencing and negotiating } & Self-confidence & $\begin{array}{l}\text { Problem-solving } \\
\text { Communication }\end{array}$ & $\begin{array}{l}\text { Changemaker } \\
\text { attributes to the }\end{array}$ \\
\hline & Perseverance & Emotional and social intelligence & Employability \\
\hline & Empathy & & Plus outcom \\
\hline
\end{tabular}

Figure 2. Two become one: uniting extra- and co-curricular work to support graduate

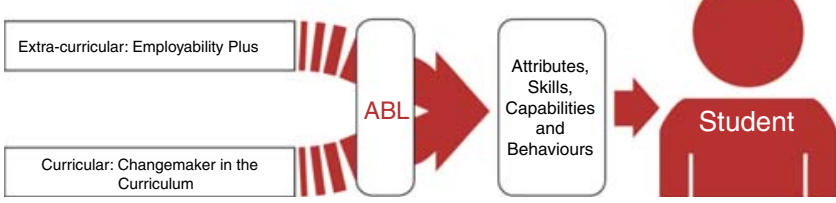
employability with the outputs of the "Changemaker in the Curriculum" project

[... them] to the criteria for a desired job" (Cavanagh et al., 2015, p. 279). ABL supports students to connect their desired employability outcomes with their discipline (Artess et al., 2016) and develop the "capacity to articulate and communicate their learning to employers" irrespective of where that skill was learned (Artess et al., 2016, p. 7; see also Rust and Froud, 2016). This is important, for one's employability can only be recognised by a potential employer if one is aware of the skills s/he possesses and can demonstrate them at interview. Together, these on-programme and extra- and co-curricular opportunities for development of personal literacy help to meet another strategic imperative currently prominent within UK HE, namely enhancement of the student experience through increased personalisation of learning. 
HESWBL 9,1

Through this reverse engineering approach, the team were able to explore how both the Changemaker Attributes and Employability Skills might be defined at different academic levels yet still reflect nuances in terms of academic discipline. Colleagues pragmatically re-grouped the skills into a framework of similar skills to accommodate the fact that not all modules would be able to support students to develop each of the 10 Employability skills. The model (Figure 1) shows how 9 of the 10 skills have been grouped under three headings: change, collaboration and self-direction, with the 10th skill - positive work ethic, integrity and values - being situated at the very centre of the model, reflecting the values and behaviours of the individual student (ultimately the graduate) seeking employment. However, for ease of use, this 10th skill was later pulled out into one of the spokes of the framework to facilitate a visual representation of the unique skills development map across each academic programme. Finally, a "mission statement" was added to the framework, providing a concise explanation of each skills grouping (top of Figure 3).

Headline statements articulate what each grouping and individual skill might look like upon graduation, i.e. at Level 6 (Table II), providing both an end-goal in respect of undergraduate programmes, and a mid-point in terms of provision across Levels 4-8 (i.e. up to $\mathrm{PhD}$ or Doctor of Professional Practice level). These statements draw heavily on the input from cross-disciplinary academic staff, professional services colleagues and from the UK Framework for Higher Education Qualifications (FHEQ) (Quality Assurance Agency, 2014). While the language used to describe the separate groupings and skills is likely to be familiar to both employers and readers, the concept of what it means to "be a Changemaker" is probably not. Consequently, the "Changemaker flavour" only emerges in the underpinning definitions. That said, similar language has become increasingly visible in recent years: in their report into employers' perceptions of new graduates' skills and abilities, Lowden et al. (2011) identified that employers are looking for graduates to evidence and demonstrate "motivation, tenacity and commitment". Other skills mentioned elsewhere include self-awareness, reflection, values, resilience, emotional intelligence, empathy and creative problem solving (Goleman, 1999; HEA, 2015; Smith and Paton, 2014; Quality Assurance Agency for Higher Education (QAA), 2018).

Explicit use of the FHEQ helps assure the development of graduate-ness in general, while incorporation of the Changemaker attributes into the employability skills definitions enables the development of the values-driven "Northampton graduate-ness" in particular (emphasis added). As an example, in the "Conceptions of Changemaker" study, staff and students referred to "Changemakers" as possessing "grit". However, when employers were presented with this terminology, the term was not well recognised, but the phrase 


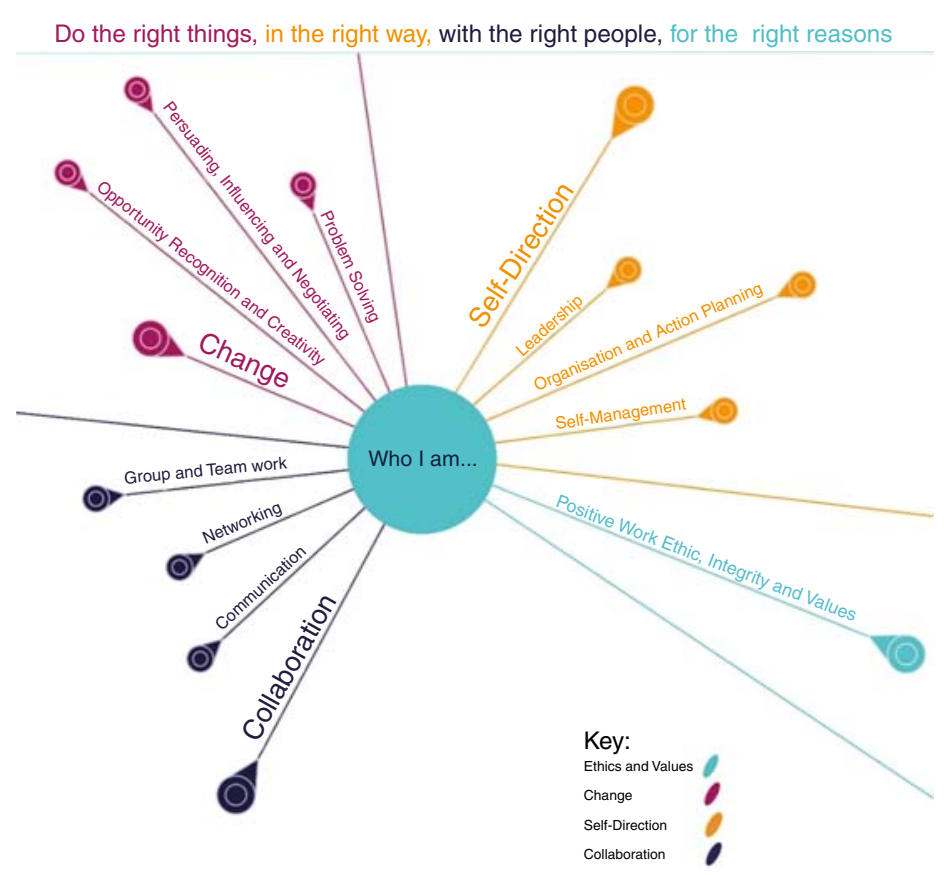

The ChANGE framework of graduate attributes

"persuading, influencing and negotiating" was. Consequently, the latter term appears in the Employability Plus skills, and "grit" only in the underpinning Changemaker attributes (Alden Rivers, Armellini and Nie, 2015).

\section{Changemaker outcomes for graduate success - the COGS toolkit}

Although work to shift pedagogic practice to ABL was already well underway, simultaneous embedding of employability skills development provided further encouragement for programme teams to engage in curriculum design and in the transformation of their own pedagogic practices. Academic development initiatives were introduced to help with ownership of the ChANGE framework, building on the co-developmental approach already in operation as part of this project. Central to this was the drafting of COGS - our award-winning[1] toolkit for the writing of level-appropriate learning outcomes that would realise the objective for the entire student body to meaningfully engage with the Changemaker and Employability agendas (Figure 4).

The COGS toolkit (Institute of Learning and Teaching in Higher Education, 2016b) draws heavily on earlier work undertaken at The University of Hull (2012). It provides staff with a breakdown of what each of the headline Changemaker and Employability statements looks like across all levels of undergraduate provision (levels 4-6) (as an example, see Table III in respect of problem solving, analysis and investigation). A postgraduate version addressing levels 7 and 8 is in development. It uses generic wording as a starting point for the writing of learning outcomes that should be tailored to the requirements of academic disciplines and the associated skill and competence elements sought by employers. Colour is used to demonstrate both conceptual and linguistic continuity across academic levels. As students' progress in their studies, a new colour is introduced to demonstrate how the demands placed upon students change as they move up an academic level. 


\section{HESWBL 9,1}

\section{4}

Table II.

Headline statements for the skills groupings and individual skills at level 6

$\begin{array}{ll}\text { Group Skill } & \text { Statement }\end{array}$

Change

Do the right things ...

Change skills Opportunity recognition and Creativity Problem solving, analysis and investigation Persuading, influencing and negotiating

Self-Direction

... in the right way

Self-direction Leadership skills

Self-management

Organisation and action planning

Collaboration

... with the right people

Collaboration Communication skills

Teamwork

Networking

Positive work-ethic, integrity and values

... for the right reasons problems
On completion of Level 6, our students are socially responsible problem solvers, who apply knowledge of their chosen field to identify, create, promote and manage opportunities for positive change

Students apply creative thinking to recognise, create and capitalise on opportunities, taking unprompted action to foster innovative, practical change

Students work independently and with others to identify, design and critically evaluate evidence-based ethical and creative solutions to

Students articulate ideas and concepts confidently and knowledgeably to a variety of audiences, demonstrating perseverance to reach consensus and obtain commitment to a shared vision

On completion of Level 6, our students use evidence, analysis and critical reflection to achieve and encourage others to generate positive, values-driven impact for themselves and their communities

Students are responsible and accountable decision makers, who apply strategies to inspire others and secure commitment to effect sustainable change

Students reflect on and evaluate their skills, take responsibility for their learning and proactively plan for personal and professional continuous development

Students define goals, prioritise and manage complex tasks, evaluate and apply resources and adapt in positive ways to changing circumstances

On completion of Level 6, our students learn and create effectively and collaboratively through meaningful professional connections with others Students communicate complex concepts, demonstrating professionalism, empathy and the ability to adapt to different audiences Students establish and maintain effective and collaborative relationships, through valuing others, handling challenges and actively reflecting upon and learning from the experience Students proactively connect with others, and exchange ideas to establish mutually beneficial working relationships

The actions and behaviours of our Level 6 students are driven by an awareness of personal values motivating them to achieve sustainable social impact

\section{Figure 4.}

$\mathrm{ABL}$ as a means to translate the curricular and co-curricular activities into tangible graduate attributes

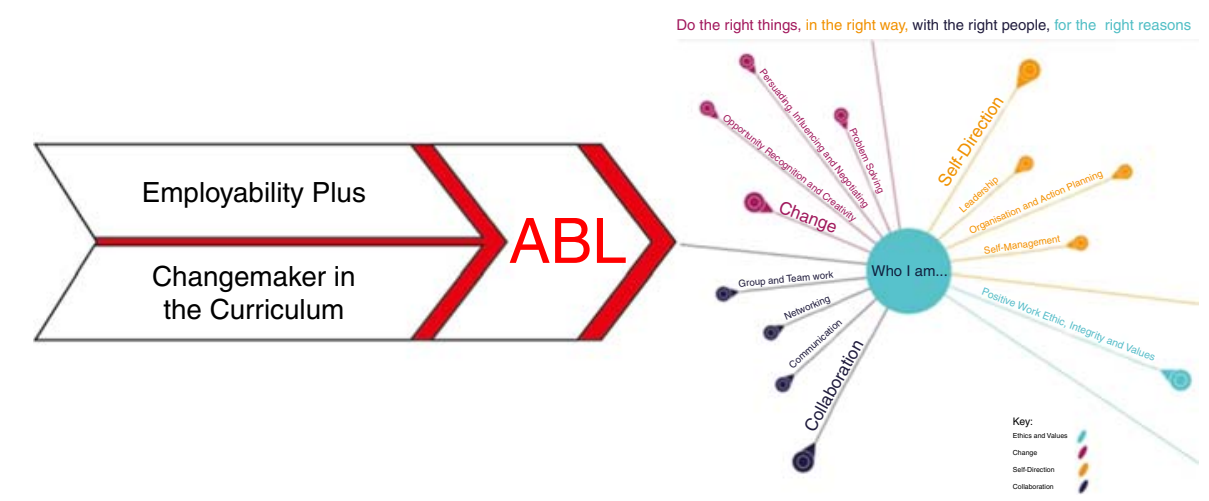




\begin{tabular}{|c|c|c|c|}
\hline \multicolumn{4}{|c|}{$\begin{array}{l}\text { On graduation, our students work independently and with others to identify, design and critically } \\
\text { evaluate evidence-based ethical and creative solutions to problems }\end{array}$} \\
\hline & Level 4/Year 1 & Level 5/Year 2 & Level 6/Year 3 \\
\hline $\begin{array}{c}\text { PREFIX } \\
\quad \ldots\end{array}$ & $\begin{array}{l}\text { With detailed guidance students } \\
\qquad \text { will be able to: }\end{array}$ & $\begin{array}{l}\text { With guidance students will be } \\
\text { able to: }\end{array}$ & $\begin{array}{l}\text { With limited guidance students } \\
\text { will be able to: }\end{array}$ \\
\hline 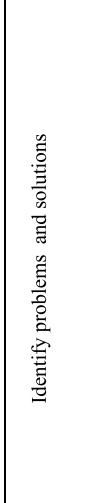 & $\begin{array}{l}\text { Identify, select and justify } \\
\text { approaches to use from a range } \\
\text { of both predefined and self- } \\
\text { generated solutions }\end{array}$ & $\begin{array}{c}\text { Identify and solve } \\
\text { straightforward problems } \\
\text { including some abstract } \\
\text { problems } \\
\text { Identify, select and justify } \\
\text { approaches to use from a range } \\
\text { of both predefined and self- } \\
\text { generated, creative solutions, } \\
\text { using clearly defined/ } \\
\text { accepted problem solving } \\
\text { strategies }\end{array}$ & $\begin{array}{c}\text { Identify and solve } \\
\text { straightforward/complex/ } \\
\text { concrete and abstract problems } \\
\text { Devise a range of creative } \\
\text { alternative solutions that justify } \\
\text { a chosen course of action, } \\
\text { drawing from/adapting } \\
\text { accepted problem solving } \\
\text { strategies }\end{array}$ \\
\hline 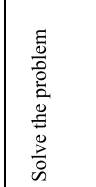 & $\begin{array}{l}\text { Implement a chosen solution to } \\
\text { a problem, demonstrating } \\
\text { consideration of ethical issues, } \\
\text { individually and with others }\end{array}$ & $\begin{array}{l}\text { Implement an ethically sound } \\
\text { solution to a (complex) } \\
\text { problem, individually and with } \\
\text { others }\end{array}$ & $\begin{array}{l}\text { Implement an ethically sound } \\
\text { solution to a complex (concrete } \\
\text { and abstract) problem, } \\
\text { individually and with others }\end{array}$ \\
\hline 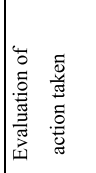 & $\begin{array}{c}\text { Evaluate the effectiveness of } \\
\text { different problem solving } \\
\text { strategies }\end{array}$ & $\begin{array}{l}\text { Critically evaluate both the } \\
\text { chosen approaches and } \\
\text { solutions to the problem }\end{array}$ & $\begin{array}{l}\text { Critically evaluate the selected } \\
\text { approaches and solutions to the } \\
\text { problem and propose a refined } \\
\text { solution }\end{array}$ \\
\hline
\end{tabular}

The ChANGE framework of graduate attributes

Table III.

The COGS toolkit elements in respect of problem-solving, analysis and investigation at undergraduate level

Support for academic staff seeking to use COGS to deploy constructively aligned curricula and evidence a pedagogic shift to ABL exists through a workshop that explores the nature of progression between the different stages of an academic programme. However, use of the Toolkit gained real traction when its use was tied to another institutional initiative, namely a wide-sweeping review of assessment practice. This initiative ensured that the progressive development and scaffolding of employability skills was aligned with the QAA FHEQ (Quality Assurance Agency for Higher Education, 2014).

As a fully transferable, Creative-Commons licensed artefact, COGS can be adapted and used by other institutions seeking to embed employability skills within their curricula. COGS is helping Northampton to realise our mission to transform lives and inspire change, as captured in the ChANGE framework (Figure 3). However, the toolkit is flexible enough to 
HESWBL 9,1

be used by other institutions to deliver their own contextualised Frameworks of Graduate Attributes. This is evidenced through successful engagement with COGS by representatives from multiple international HEIs (Armellini et al., 2016; Maxwell, 2016).

A later paper will explore the impact that the institutional adoption of COGS has had on the articulation of learning outcomes and assessment practice.

\section{Reflections on progress}

A number of benefits, both to individual students and to the University as a whole, have emerged as a result of connecting the "Changemaker in the Curriculum" initiatives. A related set of benefits arise out of the deliberate use of the same framework in curricular, extra- and co-curricular contexts. Adoption of the single framework ensured a unified approach for students to the development and enhancement of their graduate employability potential. Use of one framework also provided them with a clearer sense of ownership and agency in respect of their journey through $\mathrm{HE}$ to becoming a graduate. It helps students to own their career development and progression and be more adaptable in an increasingly complex, uncertain and changing labour-market (Cavanagh et al., 2015). Finally, it helps them to realise that the University's published graduate capabilities are directly linked to their academic studies, curriculum design and learning outcomes.

These benefits are enhanced by the introduction of ABL, which focusses on the application of knowledge and understanding and the development of relevant skills within a subject context and meets the "inclusive leadership" attribute identified by the QAA (2018) to create and shape appropriate learning environments. A shared framework for the development and articulation of these skills further supports students in bridging the gap between their existing skill sets on entry to HE study, and the critical competences they will need to demonstrate on entry to the workplace post-graduation (Shah et al., 2004; Oliver et al., 2011).

The value of the COGS toolkit in helping staff to write level-appropriate learning outcomes and thereby consistently embedding employability skills development within curricula is twofold. First, use of a generic toolkit as a starting point across all academic levels helps address a concern flagged by Cavanagh et al. (2015) about the "random and unequal" development of graduate capabilities across academic courses (p. 286). Second, the shift to ABL, in conjunction with the COGS toolkit to tailor learning outcomes to the various subject disciplines, means that the risk of "learners and instructional pedagogies [...] remain[ing] broad at entry level and continu[ing] until exit from the academic program" (Cavanagh et al., 2015, p. 285) is mitigated.

A final set of benefits accrue from use of the ABL methodology across the curriculum and now, importantly, fully adopted in the extra- and co-curricular "Employability Plus" scheme to support graduate employability. ABL itself builds on a social constructivist pedagogy that stresses participation, collaboration, active learning and social interaction, whether occurring in face-to-face or online learning environments (Rutt et al., 2013; Kumar, 2015). Its explicit focus on what learners "do" with their knowledge and understanding - their application of theory to practice - enhances the practical orientation of all programmes of study. This practical orientation, described by Grotkowska et al. (2015) as a "key vehicle of the entrepreneurial paradigm" (p. 877), helps in the development of "pragmatic and practical" skills development and "real-life" learning opportunities within programmes of study so that ultimately there is a "closer alignment between graduate and desired employability skills" (Cavanagh et al., 2015, p. 281).

\section{Limitations and risks}

As a new initiative, there is limited evidence of the impact of this work. Gaps in the students' acquisition of the attributes identified in the ChANGE Framework may occur as 
programmes can only go so far in helping students to realise all attributes. The benefits of engaging in this work are sensitive to the initiative deployed by individual students in addressing their own gaps through engagement with Employability Plus and dependent upon how far they choose to "progress into the entrepreneurship zone" (QAA, 2018). This weakness can be mitigated to an extent through Northampton's personalised approach to learning and teaching (ABL) and timetabled engagement with Employability Plus.

The extent to which employability skills development will be meaningfully addressed through academic programmes will also be dependent upon the extent to which academic colleagues engage with the embedding of employability skills in their provision. Finally, there is a risk that the Employability Plus team might revert to offering a careers service that would be incompatible with the principles outlined in this paper.

\section{The Changemaker difference and the challenges ahead}

In their review of the debate on the value of a university education, Pericles Rospigliosi et al. (2014) argue that "[t]he defining difference between graduates and non-graduates is that the former have acquired the knowledge, skills and attitudes of a university education and a proven ability and willingness to learn" (p. 424). In their exploration of "graduate employability" they talk about "graduate propensity to learn", defined further as "graduate capacity and disposition to learn" (p. 421). Within this concept, the role of HE is to both develop students' capacity and disposition to learn and certify their ability and disposition.

However, this skills development is not the "magic bullet" that can address issues of productivity and competitiveness' (Keep et al., 2006, p. 554), suggesting that more is needed if students are to stand out and secure graduate level employment. At Northampton, this additional element is the "Changemaker difference". It is important that graduates from Northampton articulate the potential of this differentiator clearly and succinctly when seeking employment post-graduation. This is particularly true if we are to mitigate against the perceived risk to employers identified in the Pericles Rospigliosi et al. study of hiring graduates from "new Universities" (like Northampton) in an increasingly flooded graduate market.

This "Changemaker difference" is most explicitly seen in the ChANGE framework descriptors and associated learning outcomes at Programme and Module level. Whether expressed through being a "socially responsible problem solver", a leader who "inspire[s] others and secure[s] commitment to effect sustainable change" or a communicator who demonstrates "empathy", the "Changemaker difference" offers a differentiator from a recruitment perspective. In explicitly incorporating these skills and attributes in learning outcomes, there is an opportunity to enable the formation of the "Northampton graduate", rather than just "graduate-ness" in general, and thereby overcome Kumar's (2015) observation that while identity formation "may be thought of as the primary purpose of $\mathrm{HE}[\ldots]$ it is often a tacit ideal that does not translate into reality" (p. 4).

In addition to arguing that to help graduates stand out in the marketplace universities need to articulate what their graduates look like; this paper also argues for the embedding of these attributes and associated employability skills within the academic disciplines as a contextualised locus for their development. Rather than considering improving one's employability potential as separate to disciplinary studies, it is apparent that embedding the former within the latter not only helps students perceive how their career goals can be achieved through their academic programme, but also restores their agency and ownership in the process and enhances the overall student experience. Furthermore, through robust curriculum design processes (Institute of Learning and Teaching in Higher Education, 2016c) that explicitly consider how Changemaker is being incorporated into academic programmes, opportunities are provided at the crucial design stage to address the assumption identified by Hager and Holland (2006, cited in Cavanagh et al., 2015, p. 279) that
The ChANGE framework of graduate attributes 
HESWBL 9,1

academic and employability skills sets are the same. In surfacing areas of convergence and divergence at the design stage, it is possible to highlight where students may need to engage with co- or extra-curricular activities to address any gaps.

\section{Conclusions}

Through introduction of the ChANGE framework and the associated COGS learning outcomes toolkit, this paper informs the wider debate on employability in the UK Higher Education context. Together, this framework and toolkit can help to foster individual employability skills development in general, and graduate employability skills development in particular. The combined use of these artefacts supports the emerging shift in discourse from employability skills per se, to the development of a graduate identity.

This approach also supports students in the development of their personal literacy, ensuring that they not only possess the requisite employability skills but, crucially, they can articulate them upon entry into the labour market. Within the Northampton context, graduate identity is encapsulated in our values-driven "Changemaker difference" and articulated through the ChANGE framework with its accompanying definitions for skills and attributes. The fact that this shift in discourse has been achieved successfully at Northampton suggests that there is value for other HEPs in articulating their own unique concepts of "graduate-ness" as a differentiator in the labour market - a point that has been recognised most recently by the QAA (2018).

In taking deliberate action to embed Changemaker attributes within curricula, Northampton is seeking to implement meaningful, systemic, embedded change, boldly articulated in its mission to transform lives and inspire change. Student-centredness occurs both through a learner-centred pedagogy (ABL) that is predicated upon active participation, collaboration and interactivity, and an extra- and co-curricular employability service that adopts a similar methodology and uses the same framework, thereby complementing and scaffolding the academic programme. Although in the early stages of implementing the use of the ChANGE framework in academic programmes, the exponential increase in engagement with "Changemaking", extra- and co-curricular employability skills development through "Employability Plus", is indicative of the value of the combined approach to our student body. The next stage is to support academic colleagues to use the COGS toolkit to write learning outcomes at programme and module level that draw on the ChANGE attributes. In this way, the attributes garner meaning within a subject discipline through constructively aligned assessment practice that supports student progression through the different stages of their studies. It will also be valuable to explore the impact of these new Employability and Changemaker learning outcomes on constructively aligned assessment design and delivery, particularly in the context of the QAA's (2018) differentiation between learning "about", learning "for" and learning "through" entrepreneurship (p. 14).

\section{Acknowledgements}

The authors would like to acknowledge the considerable input from the following colleagues in the development of the ChANGE Framework and the COGS toolkit in particular: Shirley Bennett, Wray Irwin, Elizabeth Palmer and Julie Usher. In addition, input was received from colleagues across all academic schools and Faculties, as well as other professional services colleagues and members of The University of Northampton Students' Union to the development of these artefacts. Special thanks to Elizabeth Palmer for her assistance in producing a graphical representation of the ChANGE Framework and to Juan Pablo Armellini for supporting us with the graphical representation of all other figures. 
Note

1. The COGS Learning Outcomes Toolkit was a recipient of one of the 2018 AshokaU Innovation Awards.

\section{References}

Alden Rivers, B., Armellini, A. and Nie, M. (2015), "Embedding social innovation and social impact across the disciplines: identifying 'changemaker' attributes", Higher Education, Skills and Work-Based Learning, Vol. 5 No. 3, pp. 242-257.

Alden Rivers, B., Nie, M. and Armellini, A. (2015), "University teachers' conceptions of 'changemaker': a starting point for embedding social innovation in learning and teaching", Education + Training, Vol. 57 No. 5, pp. 588-600.

Alden Rivers, B., Armellini, A., Maxwell, R., Allen, S. and Durkin, C. (2015), "Social innovation education: towards a framework for learning design", Higher Education, Skills and Work-Based Learning, Vol. 5 No. 4, pp. 383-400.

Andrews, G. and Russell, M. (2012), "Employability skills development: strategy, evaluation and impact", Higher Education, Skills and Work-Based Learning, Vol. 2 No. 1, pp. 33-44.

Armellini, A., Maxwell, R. and Palmer, E. (2016), "Reconceptualising and embedding graduate attributes for enhanced employability", Pre-Conference Workshop at Online Educa Berlin 2016: Shaping the Future of Learning, Berlin, 30 November.

Artess, J., Hooley, T. and Mellors-Bourne, R. (2016), "Employability: a review of the literature 2012-2016”, A report for the Higher Education Academy, Higher Education Academy, York.

Biggs, J. and Tang, C. (2011), Teaching for Quality Learning at University: What the Student Does, 4th ed., McGraw Hill/Society for Research into Higher Education/Open University Press, Maidenhead.

Blackmore, P., Bulaitis, Z.H., Jackman, A.H. and Tan, E. (2016), Employability in Higher Education: A Review of Practice and Strategies Around the World, Pearson, London, available at: www. pearson.com/uk/about-us/news-and-policy/reports-and-campaigns/employability-in-highereducation.html (accessed 17 March 2017).

Cavanagh, J., Burston, M., Southcombe, A. and Bartram, T. (2015), "Contributing to a graduate-centred understanding of work readiness: an exploratory study of Australian undergraduate students' perceptions of their employability", The International Journal of Management Education, Vol. 13 No. 2015, pp. 278-288.

Cutts, B., Hooley, T. and Yates, J. (2015), “Graduate dress code: how undergraduates are planning to use hair, clothes and make-up to smooth their transition to the workplace", Industry and Higher Education, Vol. 29 No. 4, pp. 271-282.

Daniels, J. and Brooker, J. (2014), "Student identity development in higher education: implications for graduate attributes and work-readiness", Educational Research, Vol. 56 No. 1, pp. 65-76, available at: www.tandfonline.com/doi/full/10.1080/00131881.2013.874157?scroll=top\& needAccess=true (accessed 17 March 2017).

Goleman, D. (1999), Working with Emotional Intelligence, Bloomsbury, London.

Greenbank, P. (2015), "Still focusing on the 'essential 2:1': exploring student attitudes to extra-curricular activities", Education \& Training, Vol. 57 No. 2, pp. 184-203.

Grotkowska, G., Wincenciak, L. and Gajderowicz, T. (2015), "Ivory-tower or market-oriented enterprise: the role of higher education institutions in shaping graduate employability in the domain of science", Higher Education Research \& Development, Vol. 34 No. 5, pp. 869-882, available at: www.tandfonline.com/doi/full/10.1080/07294360.2015.1011090 (accessed 17 March 2017).

Hager, P. and Holland, S. (Eds) (2006), Graduate Attributes, Learning and Employability, Springer, Dordrecht, pp. 17-47, cited in Cavanagh et al. (2015).

Higher Education Academy (2015), Framework for Embedding Employability in Higher Education, Higher Education Academy, York, available at: www.heacademy.ac.uk/institutions/ consultancy/frameworks/employability (accessed 28 March 2017).
The ChANGE framework of graduate attributes 
HESWBL 9,1
Hinchliffe, G.W. and Jolly, A. (2011), "Graduate identity and employability", British Educational Research Journal, Vol. 37 No. 4, pp. 563-584.

Holmes, L. (2001), “Reconsidering graduate employability: the 'graduate identity' approach”, Quality in Higher Education, Vol. 7 No. 2, pp. 111-119.

Institute of Learning and Teaching in Higher Education (2016a), Defining Active Blended Learning, Institute of Learning and Teaching in Higher Education, Northampton, available at: www. northampton.ac.uk/ilt/current-projects/defining-abl/ (accessed 3 March 2017).

Institute of Learning and Teaching in Higher Education (2016b), Changemaker Outcomes for Graduate Success (COGS) Toolkit for Writing Learning Outcomes, Institute of Learning and Teaching in Higher Education, Northampton, available at: www.northampton.ac.uk/ilt/current-projects/ change/cogs/ (accessed 3 March 2017).

Institute of Learning and Teaching in Higher Education (2016c), Introduction to CAIeRO, Institute of Learning and Teaching in Higher Education, Northampton, available at: www.northampton.ac. uk/ilt/academic-development/caiero/ (accessed 31 March 2017).

Kalfa, S. and Taksa, L. (2015), "Cultural capital in business higher education: reconsidering the graduate attributes movement and the focus on employability", Studies in Higher Education, Vol. 40 No. 4, pp. 580-595.

Keep, E., Mayhew, K. and Payne, J. (2006), "From skills revolution to productivity miracle - not as easy as it sounds?", Oxford Review of Economic Policy, Vol. 22 No. 4, pp. 539-559, available at: https:// academic.oup.com/oxrep/article/22/4/539/412125/From-Skills-Revolution-to-Productivity-MiracleNot (accessed 31 March 2017).

Kumar, A. (2015), Enabling all Learners to SOAR for Employability: An Inclusive, Integrative Pedagogy, Higher Education Academy, York, available at: www.heacademy.ac.uk/enabling-all-learnerssoar-employability-inclusive-integrative-pedagogy (accessed 17 March 2017).

Lowden, K., Hall, S., Elliot, D. and Lewin, J. (2011), Employers' Perceptions of the Employability Skills of New Graduates, Edge Foundation, London.

Marringe, F. and Foskett, N. (Eds) (2010), "Globalization and internationalization in higher education: theoretical strategic and management perspectives", London and New York, NY, Continuum International Publishing Group cited in Cavanagh, J., Burston, M., Southcombe, A. and Bartram, T. (2015), "Contributing to a graduate-centred understanding of work readiness: an exploratory study of Australian undergraduate students' perceptions of their employability", The International Journal of Management Education, Vol. 13, pp. 278-288.

Maxwell, R. (2016), "Designing learning to inspire social change”, Workshop at Utah Valley University, Orem, Utah, 31 March.

Oliver, B., Whelan, B., Hunt, L. and Hammer, S. (2011), "Accounting graduates and the capabilities that count: perceptions of graduates, employers and accounting academics in four Australian universities", Journal of Teaching and Learning for Graduate Employability, Vol. 2 No. 1, pp. 2-27, available at: www.researchgate.net/publication/264004293_Accounting_graduates_and_the_ capabilities_that_count_Perceptions_of_graduates_employers_and_Accounting_academics_ in_four_Australian_universities (accessed 31 March 2017).

Oria, B. (2012), "Enhancing higher education students' employability: a Spanish case study", International Journal of Technology Management and Sustainable Development, Vol. 11 No. 3, pp. 217-230, available at: http://web.b.ebscohost.com/ehost/pdfviewer/pdfviewer?sid=3a5dd281c79f-4e7f-8106-1bc6d3c4efba\%40sessionmgr120\&vid=2\&hid=118 (accessed 31 March 2017).

Oxford Brookes University (2010), Strategy for Enhancing the Student Experience 2010-2015, Oxford Brookes University, Oxford, available at: www.brookes.ac.uk/ocsld/your-development/teachingand-learning/sese/ (accessed 9 August 2017).

Pemberton, J., Jewell, S., Faggian, A. and King, Z. (2013), "Higher education as a portfolio investment: students' choices about studying, term time employment, leisure, and loans", Oxford Economic Papers, Vol. 65 No. 2, pp. 268-292, available at: https://academic.oup.com/oep/article/65/2/268/2 912959/Higher-education-as-a-portfolio-investment (accessed 31 March 2017). 
Pericles Rospigliosi, A., Greener, S., Bourner, T. and Sheehan, M. (2014), "Human capital or signalling, unpacking the graduate premium", International Journal of Social Economics, Vol. 41 No. 5, pp. $420-432$.

Quality Assurance Agency for Higher Education (2014), "UK quality code for higher education. Part A: setting and maintaining academic standards. The frameworks for higher education qualifications of UK degree-awarding bodies", available at: www.qaa.ac.uk/publications/ information-and-guidance/publication?PubID=2843\#.WLmN4UehO25 (accessed 3 March 2017).

Quality Assurance Agency for Higher Education (QAA) (2018), "Enterprise and entrepreneurship education: The ChANGE framework of graduate attributes guidance for UK higher education providers", available at: www.qaa.ac.uk/en/Publications/ Documents/Enterprise-and-entrpreneurship-education-2018.pdf (accessed 24 April 2018).

Rich, J. (2015), "Employability: degrees of value", Higher Education Policy Institute Occasional Paper, Vol. 12, available at: www.hepi.ac.uk/2015/12/10/employability-degrees-value/ (accessed 31 March 2017).

Rust, C. and Froud, L. (2016), "Shifting the focus from skills to 'graduateness'”, Phoenix, Vol. 148, June, pp. 8-9.

Rutt, L., Gray, C., Turner, R., Swain, J., Hulme, S. and Pomeroy, R. (2013), "A social constructivist approach to introducing skills for employment to foundation degree students", Research in Post-Compulsory Education, Vol. 18 No. 3, pp. 280-296.

Shah, A., Pell, K. and Brooke, P. (2004), "Beyond first destinations: graduate employability survey", Active Learning in Higher Education, Vol. 5 No. 1, pp. 9-26.

Smith, A.M.J. and Paton, R. (2014), "Embedding enterprise education: A service based transferable skills framework", International Journal of Management Education, Vol. 12 No. 3, pp. 550-560, available at: www.sciencedirect.com/science/article/pii/S1472811714000068 (accessed 3 March 2017).

The University of Hull (2012), A University of Hull Learning Outcomes Tool in The University of Hull Quality Handbook 2012, University of Hull, Hull.

The University of Northampton (2015), Transforming Lives + Inspiring Change: Strategic Plan 2015-2020, The University of Northampton, Northampton.

Wilton, N. (2014), "Employability is in the eye of the beholder: employer decision-making in the recruitment of work placement students", Higher Education, Skills \& Work-Based Learning, Vol. 4 No. 3, pp. 242-255.

Yorke, M. (2006), Employability in Higher Education: What it is - What it is Not. (Learning and Employability Series 1), Higher Education Academy, York, available at: www.employability.ed. ac.uk/documents/.../HEA-Employability_in_HE(Is,IsNot).pdf (accessed 3 March 2017).

Yorke, M. and Knight, P.T. (2006), Embedding Employability into the Curriculum. Learning and Employability Series One, Higher Education Academy, York, available at: www.heacademy.ac. uk/resource/embedding-employability-curriculum (accessed 3 March 2017).

\section{Further reading}

Confederation of British Industry and National Union of Students (2011), Working Towards Your Future: Making the Most of Your Time in Higher Education, Confederation of British Industry, London, available at: www.nus.org.uk/Global/CBI_NUS_Employability\%20report_May\%202011.pdf (accessed 3 March 2017).

Wilson, T. (2012), A Review of Business-University Collaboration, Department for Business Innovation and Skills, London, available at: www.gov.uk/government/uploads/system/uploads/ attachment_data/file/32383/12-610-wilson-review-business-university-collaboration.pdf (accessed 3 March 2017).

\section{Corresponding author}

Rachel Maxwell can be contacted at: rachel.maxwell@northampton.ac.uk

For instructions on how to order reprints of this article, please visit our website:

www.emeraldgrouppublishing.com/licensing/reprints.htm

Or contact us for further details: permissions@emeraldinsight.com 